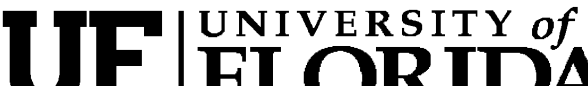 FLORIDA \\ IFAS Extension
}

\section{Gray Leaf Spot of St. Augustinegrass: Cultural and Chemical Management Options ${ }^{1}$}

\author{
P. Harmon, L. Datnoff, R. Nagata, M. Brecht, and C. Stiles ${ }^{2}$
}

Gray leaf spot disease, caused by the fungus Pyricularia grisea (also referred to as Magnaporthe grisea), slows grow-in, thins established stands, and can kill large areas of St. Augustinegrass turf during the frequent warm rainy periods associated with Florida. In Florida, St. Augustinegrass is the only warm season turfgrass affected by this important disease. However, from the mid-Atlantic states north and throughout much of the Midwest, the pathogen blights the cool season species of annual and perennial ryegrass as well as tall fescue.

\section{Disease Symptoms and Occurrence}

Warm rainy spells from May through September commonly produce extended periods (12 hours and greater) of leaf wetness and relative humidity greater than $95 \%$. During these periods, turfgrass leaf blades can remain wet and air temperatures often hover between 80 and 90 degrees Fahrenheit.

Environmental conditions such as these are ideal for the pathogen growth, infection, and colonization of St. Augustinegrass. If these favorable conditions persist, leaf spots can expand to blight above-ground plant tissue.

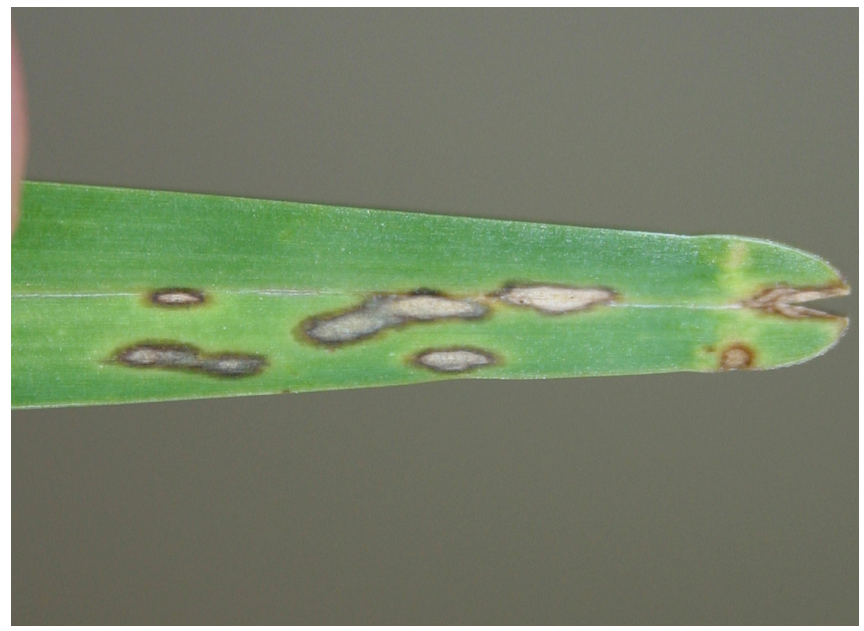

Figure 1. Leaf spot symptoms of gray leaf spot are shown on a St. Augustinegrass leaf blade. The gray coloration in the center of the lesions is a flush of spores produced after incubation at $100 \%$ relative humidity for $24 \mathrm{hr}$. Rapidly expanding lesions will sometimes have an olive green water-soaked border. Credits: Phil Harmon

1. This document is PP204, one of a series of the Plant Pathology Department, Florida Cooperative Extension Service, Institute of Food and Agricultural Sciences, University of Florida. Original publication date March 2005. Visit the EDIS Web Site at http://edis.ifas.ufl.edu.

2. Philip Harmon, assistant professor, Plant Pathology Department; Lawrence Datnoff, professor, Plant Pathology Department; Russell Nagata, professor, Horticultural Sciences Department, Everglades Research and Education Center--Belle Glade, FL; Matt Brecht, graduate research assistant, Plant Pathology Department; Carol Stiles, assistant professor, Plant Pathology Department; Florida Cooperative Extension Service, Institute of Food and Agricultural Sciences, University of Florida, Gainesville, FL 32611.

The use of trade names in this publication is solely for the purpose of providing specific information. UF/IFAS does not guarantee or warranty the products named, and references to them in this publication does not signify our approval to the exclusion of other products of suitable composition. All chemicals should be used in accordance with directions on the manufacturer's label. 


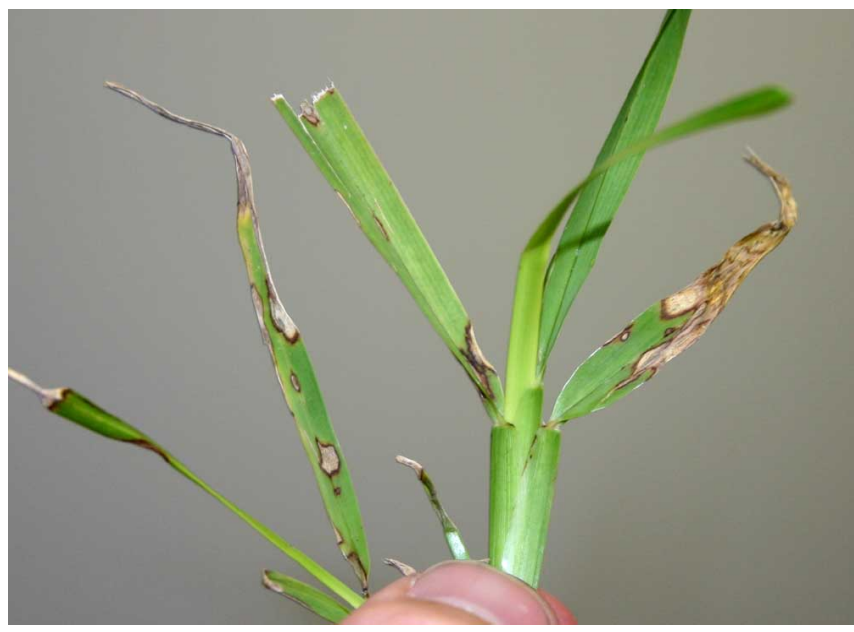

Figure 2. Gray leaf spot caused by Pyricularia grisea on a shoot of St. Augustinegrass. Lesion centers are straw-colored and surrounded by a dark necrotic border. Lesions may appear on the leaf blades, leaf sheaths, and stolons. Credits: Phil Harmon

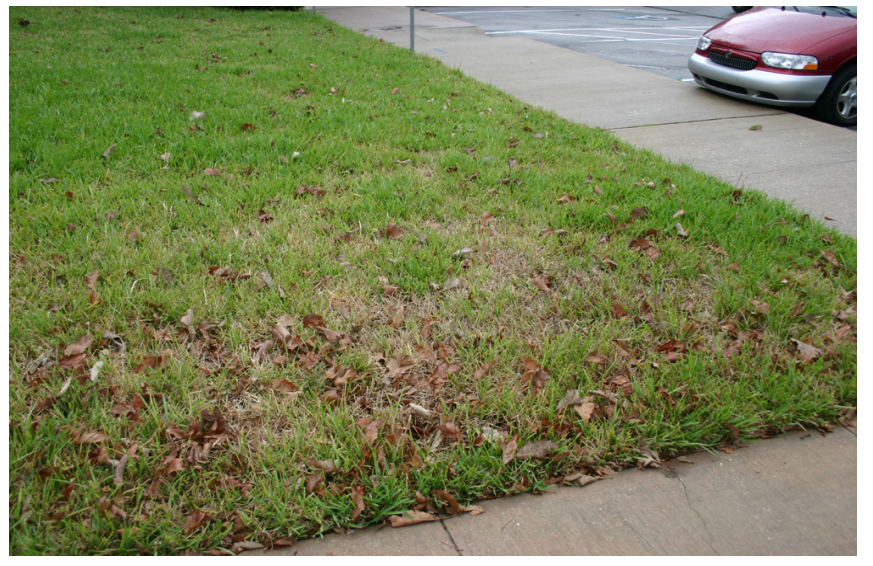

Figure 3. Established stands of St. Augustinegrass that are stressed may turn chlorotic, thin, and take on a generally unthrifty appearance when affected by gray leaf spot. Closer inspection will reveal many leaf spots on individual shoots. Credits: Phil Harmon

The most diagnostic disease symptom is an oblong leaf spot, the center of which may have a gray felt-like growth of sporulation after extended periods of warm moist conditions (Figure 1). A leaf spot may appear olive green to brown with a dark brown border when sporulation is not present (Figure 2). When the disease is severe, stands may appear thin and generally unthrifty (Figure 3). Closer inspection will reveal several leaf spots, many of which may have coalesced to turn entire blades or shoots brown. The disease generally reduces vigor of the turf and can slow grow-in of sprigged areas and the recovery of damaged St. Augustinegrass (Figure 4).

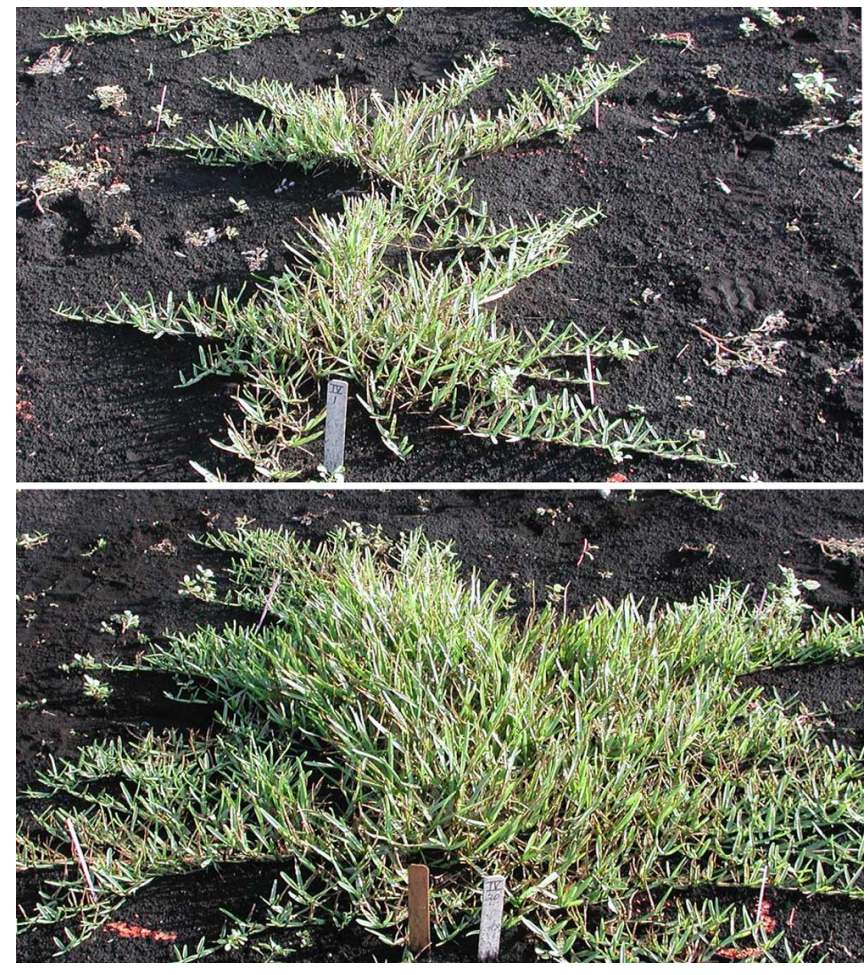

Figure 4. Gray leaf spot can substantially reduce vigor and can prolong the grow-in phase of St. Augustinegrass sprigged for sod production. Both sprigs in the figure were planted at the same time, but only the plot on the bottom was treated with a Qol fungicide product to prevent gray leaf spot. Credits: Lawrence Datnoff

Cultivars of St. Augustinegrass differ in their susceptibilities to gray leaf spot. The disease develops more rapidly and more severely on lush leaf tissue associated with rapid growth of newly-sprigged and establishing turf than on well-established stands of turfgrass. However, excessive applications of nitrogen fertilizer can result in rapid flushes of quite susceptible lush growth in mature stands. St. Augustinegrass under stress is more susceptible to infection and disease development than healthy vigorous turfgrass. Stress generally results from improper management practices that could include summer applications of the herbicide atrazine, soil compaction, nutrient imbalances or deficiencies, improper irrigation practices, other pathogens or pests, and other factors.

\section{Disease Management}

Several characteristics should be considered before new sod is purchased and installed, or before a cultivar is chosen to produce sod including susceptibility to gray leaf spot, chinch bug resistance, 
and shade tolerance. Weight given to these and other factors will depend on the market, site, level of management, and expected performance of the turf. No cultivar of St. Augustinegrass currently on the market is immune to gray leaf spot, but some cultivars are less susceptible than others (Figure 5).

\begin{tabular}{|c|c|}
\hline Cultivar & Rel ative susceptibility ${ }^{1}$ \\
\hline \multicolumn{2}{|c|}{ FX-10] } \\
\hline \multicolumn{2}{|c|}{ Common } \\
\hline \multicolumn{2}{|c|}{ Raleigh } \\
\hline \multicolumn{2}{|c|}{ Seville $\rightleftharpoons$} \\
\hline \multicolumn{2}{|c|}{ MSA-31 } \\
\hline Classic & 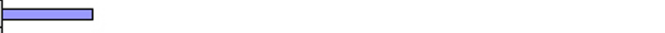 \\
\hline \multicolumn{2}{|l|}{ Rosehwn } \\
\hline \multicolumn{2}{|l|}{ Levi } \\
\hline \multicolumn{2}{|l|}{ MSA-10 } \\
\hline \multicolumn{2}{|l|}{ Palret to } \\
\hline \multicolumn{2}{|l|}{ Floratine } \\
\hline \multicolumn{2}{|l|}{ FHSA-115 } \\
\hline \multicolumn{2}{|l|}{ Florabum } \\
\hline \multicolumn{2}{|l|}{ Winchester } \\
\hline \multicolumn{2}{|c|}{$\begin{array}{c}\text { Bitte blue } \\
\text { Floratam }\end{array}$} \\
\hline \multicolumn{2}{|l|}{ Texas Common } \\
\hline \multicolumn{2}{|l|}{ NC-21-25 } \\
\hline \multicolumn{2}{|c|}{ FHSA-117 $=$} \\
\hline TAM\#9 & 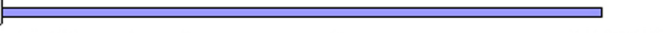 \\
\hline $\begin{array}{l}{ }^{1} \text { Relative sus } \\
\text { TAM W was }\end{array}$ & $\begin{array}{l}\text { eptibility was based on area under disease progress curves (AUDPC) } \\
\text { the cultivar most susceptible to gray leaf spot tested. }\end{array}$ \\
\hline
\end{tabular}

Figure 5. Relative susceptibility of currently available and experimental cultivars of St. Augustinegrass to gray leaf spot caused by Pyricularia grisea. Cultivars are listed from the least susceptible (most resistant) to the most susceptible (least resistant). Credits: Russell Nagata and Lawrence Datnoff

Proper irrigation management should prevent drought-stressed turfgrass without increasing disease pressure by extending periods of leaf wetness. For example, applications made in early morning generally dry quickly on sunny days; limiting favorable (wet) conditions for growth of the pathogen. Late afternoon or early evening irrigation often allows foliage to remain wet into the evening, through the dew period, and into the next morning and should be avoided. Extended periods of leaf wetness favor infection and spread of the pathogen and increase the likelihood of disease (disease pressure).

Management practices that minimize stress and avoid excessive flushes of lush rapid growth during the rainy season lessen the likelihood that severe gray leaf spot symptoms will develop. Choose the timing of any atrazine application carefully, since this chemistry can stress the grass especially when temperatures may climb above $85^{\circ} \mathrm{F}$. Atrazine applications made before or during disease-favorable conditions increase the likelihood of severe gray leaf spot symptom development. Consider spot-treating trouble areas with the herbicide. Follow UF/IFAS recommendations on St. Augustinegrass management practices including fertilizer selection and application (http://edis.ifas.ufl.edu/LH010). In addition to maintaining turf vigor and health through good management practices, plant-available silicon applied just before sprigging has been shown to suppress gray leaf spot development. For more information on the role of silicon in suppressing gray leaf spot, visit http://edis.ifas.ufl.edu/PP114.

Fungicide applications are important control options for St. Augustinegrass sod producers. Research at UF IFAS has shown that fungicide applications made after sprigging during the grow-in enhance horizontal growth and increase the rate of bare ground coverage when disease pressure is high. Some example fungicide products labeled for sod production along with their relative efficacies are listed in Table 1. Best results occur when fungicides are applied preventatively, according to the label, and while environmental conditions are favorable for disease development during the grow-in. Strobilurin (QoI) fungicides such as Insignia and Heritage are among the most effective available. Sterol inhibiting fungicides (DMI) such as Banner Maxx 1.3ME provide some control but are most effective when tank-mixed with strobilurin products when disease pressure is high. The contact fungicide chlorothalonil is effective if applied frequently, when disease pressure is moderate to low, or as a tank-mix partner with one of the more effective systemic chemistries. Additional fungicide products for gray leaf spot control are available.

Strobilurin resistant populations of the pathogen have been identified in the Midwest. Resistance management strategies found on product labeling should be followed. Rotations of products with different modes of action and tank-mixing systemic products with contact fungicides reduce the likelihood of fungicide resistance.

\section{Homeowner management options}

Gray leaf spot is chronic but not typically damaging in established, well-managed home lawns. Disease symptoms may become severe if the turf is stressed due to poor management or a poor (shady, 
damp) location or if unusually long periods of warm wet weather persist.

If the disease becomes a serious and persistent problem that requires attention, it is recommended that homeowners seek the services of a professional lawn care firm for management of the disease and/or lawn. Some homeowners have the equipment and knowledge required to correctly make a fungicide application on their own, including all safety equipment. If such homeowners understand the risks to both themselves and the environment, some of the fungicide chemistries listed in Table 1 are available through garden centers and internet catalogs. For example, propiconazole is the active ingredient in the fungicide product Ortho Lawn Disease Control. Not all fungicides are labeled for residential lawns. Results can be erratic, because applications are difficult to make properly. Because the homeowner pesticide market and product availability can change, consult your local county extension agent or university specialist for up-to-date product recommendations.

Any person who applies pesticides should always read, understand, and follow all label instructions prior to use. Specific products are listed for example only. Neither inclusion of products nor omission of similar alternative products in this publication is meant to imply any endorsement or criticism.

\section{Related Resources}

- EDIS gray leaf spot general information http://edis.ifas.ufl.edu/LH047

- St. Augustinegrass for Florida Lawns http://edis.ifas.ufl.edu/LH010

- University of Florida Extension Plant Disease Clinic. http://plantpath.ifas.ufl.edu/pdc/Default.htm

- University of Florida Pest Control Guide for Turfgrass Managers, updated yearly. http://turf.ufl.edu

- Turfgrass Disease Management. http://edis.ifas.ufl.edu/LH040
- Florida Cooperative Extension's Electronic Data Information Source (EDIS) http://edis.ifas.ufl.edu/

- Collecting and Submitting Turf Samples for Disease Diagnosis http://edis.ifas.ufl.edu/LH041 
Table 1. Fungicides effective in controlling Gray Leaf Spot of St. Augustinegrass.

\begin{tabular}{|c|c|c|c|}
\hline Fungicide & Product & Activity & Relative efficacy ${ }^{1}$ \\
\hline pyraclostrobin $^{2}$ & Insignia & local systemic & $\star \star * *$ \\
\hline azoxystrobin $^{2}$ & Heritage & local systemic & $* * *$ \\
\hline trifloxystrobin $^{2}$ & Compass & local systemic & ** \\
\hline propiconazole $^{2}$ & Banner Maxx & local systemic & * \\
\hline chlorothalonil & Daconil Weather Stik & contact & * \\
\hline \multicolumn{4}{|c|}{$\begin{array}{l}1_{* * *} \text { provides greatest efficacy under disease-favorable conditions } \\
* \text { good management tool under moderate to low disease pressure } \\
{ }^{*} \text { provides some control, best used in rotation or tank mix with other chemistries } \\
{ }^{2} \text { Risk of resistance. Resistance management required for these fungicides. }\end{array}$} \\
\hline
\end{tabular}

